\title{
Will funding to Reduce Emissions from Deforestation and (forest) Degradation (REDD+) stop conversion of peat swamps to oil palm in orangutan habitat in Tripa in Aceh, Indonesia?
}

\author{
Hesti Lestari Tata • Meine van Noordwijk • \\ Denis Ruysschaert • Rachmat Mulia • Subekti Rahayu • \\ Elok Mulyoutami • Atiek Widayati • Andree Ekadinata • \\ Riswan Zen • Adji Darsoyo • Rahayu Oktaviani • \\ Sonya Dewi
}

Received: 22 February 2013 / Accepted: 17 October 2013 /Published online: 31 October 2013

(C) The Author(s) 2013. This article is published with open access at Springerlink.com

\begin{abstract}
Tripa is the last remaining peat-swamp forest that harbours a potentially viable Sumatran orangutan (Pongo abelii) sub-population in a formally but not effectively protected area. It appears to be a simple showcase where current efforts to financially support reducing emissions from deforestation and forest degradation (REDD+) converge with biodiversity and social co-benefits. In practice, however, situation is more complex. REDD+ efforts interact with global palm oil trade and regulatory approaches (the moratorium) to achieve national goals for emissions reduction under umbrella of nationally appropriate mitigation actions (NAMA). To contextualize this debate, we assessed (i) land-use history and formal basis of palm-oil companies' rights; (ii) carbon (C) stocks, historical emission levels and potential emissions that can be avoided; (iii) economic benefits of land-use options and opportunity costs of avoiding emissions; (iv) biodiversity and environmental services; and (v) alternative options for "high C stock development" and employment generation. Natural forest cover declined (54\% in 1995, $18 \%$ in 2009) while oil palm increased 4-39\%. Aboveground C stocks decreased from $148 \mathrm{Mg} \mathrm{ha}^{-1}$ in 1990 to $61 \mathrm{Mg} \mathrm{ha}^{-1}$ in 2009 , leading to average annual
\end{abstract}

H. L. Tata $(\bowtie) \cdot$ M. van Noordwijk $(\bowtie) \cdot$ R. Mulia $\cdot$ S. Rahayu $\cdot$ E. Mulyoutami $\cdot$ A. Widayati

A. Ekadinata $\cdot$ R. Oktaviani $\cdot$ S. Dewi

World Agroforestry Centre (ICRAF), Bogor, Indonesia

e-mail: h.tata@cgiar.org

e-mail: m.vannoordwijk@cgiar.org

H. L. Tata

Forest Research and Development Agency (FORDA), Bogor, Indonesia

D. Ruysschaert

PanEco Foundation, Berg, Switzerland and Université Toulouse-Le-Mirail, Toulouse, France

R. Zen · A. Darsoyo

Yayasan Ekosistem Lestari (YEL), Medan, Indonesia 
emissions of $14.5 \mathrm{Mg}$ (carbon dioxide) $\mathrm{CO}_{2} \mathrm{e} \mathrm{ha}^{-1}$ year $^{-1}$. While $41 \%$ of these emissions yield less than American Dollar (USD) 5 of current economic benefits per $\mathrm{Mg} \mathrm{CO}_{2} \mathrm{e}$ emitted and might be compensated by REDD+, nearly all new emissions derive from a breach of existing laws, regulations and voluntary palm-oil standards. Substantial investment in alternative employment is needed, rather than carbon payments per se, to support livelihoods in a low carbon emissions economy.

Keywords Avoided deforestation · Carbon market - Eco-certification · FALLOW model · Nationally Appropriate Mitigation Actions (NAMA) · Scenario studies

\section{Introduction}

In 2010, a number of food-processing companies announced that they had cancelled contracts with oil-palm (Elaeis guineensis) companies publicly associated with deforestation in Indonesia. Orangutans (Pongo spp.) as a flagship species for conservation had become iconic in the debate on oil palm (Koh and Wilcove 2007; Butler et al. 2009; Venter et al. 2009; Nantha and Tisdell 2009; Gaveau et al. 2009; Wilcove and Koh 2010; Yule 2010). As a consequence of public pressure, it may no longer be economically right for an oil-palm company that wants to maintain market share in Europe or North America to convert primary forest on deep peat-swamp that is habitat for the highly endangered Sumatran orangutan (Pongo abelii), even if the company has the formal right to do so and if that action would be outside of the reach of international arrangements for reducing emissions from deforestation and forest degradation (REDD+).

International consumer pressure has thus become a third element in the public - private dynamic; one that is beyond regulations and positive incentives to achieve conservation. The limits of all three are currently being tested in a coastal peat-swamp in Aceh province on the island of Sumatra in Indonesia. Stopping the conversion of this type of habitat is what the outside world expected when Indonesia committed to achieve REDD+ and to a moratorium on permits to convert primary forests and peatlands.

Outside of the national parks and formally protected areas in North Sumatra and Aceh provinces, the Sumatran orangutan and humans still share landscapes that consist of remaining natural forest, forests that have been modified by human use, agroforests created by farmers, open farm land and settlements (Tata et al. 2010; Wich et al. 2008). In the case study of the Tripa swamp (Ruysschaert et al. 2009) described here, conversion to oil palm has, indeed, been the major threat. In May 2011, parts of Tripa were included in a 2-year moratorium on the issuance of new permits (Murdiyarso et al. 2011), which has been extended until May 2015 according to the Instruction of the President of the Republic of Indonesia no. 6/2013. In August 2011, the Governor of Aceh nevertheless signed a permit for further oil-palm development in the area; in the November 2011 revision of the moratorium map, the area was taken out of the reach of the Presidential Decree but the permit of August was illegal. The issue subsequently became a test case of how the different authorities and government levels in Indonesia interact. A recent court decision supported conservation of the area while international pressure focussed the attention of the governmental task force aimed at streamlining cross-scale and cross-sectoral government procedures.

In our case study of Tripa, multiple perspectives emerged on rights and right/wrong or desirable/undesirable. As the formal REDD+ negotiations internationally have not yet clarified attribution for reduction in emissions that derive from self-regulation in international trade, the Tripa swamp is a case study for exploring the potential for synergy across multiple 
incentives - positive and negative - to achieve global benefits while satisfying legitimate demands for rural development.

The costs of reducing emissions can be grouped into three categories: (i) transaction and negotiation costs; (ii) opportunity costs for foregone economic benefits that would have been associated with a "business as usual" pattern of land-use change; and (iii) implementation costs. Of these cost categories, the opportunity costs are the most open to empirical analysis at this time; they are also likely to vary substantially between different types of land-use change (White et al. 2010). If opportunity costs are high, other costs do not need to be considered as deals are unlikely to emerge; where opportunity costs are low the other cost types become the focus of debate. We examined the opportunity costs of each land use in Tripa.

The study centred on a set of interconnected questions.

(i) What is the formal basis of the companies' rights to convert forest and what are the options for governments at local, provincial and national levels to revoke licenses and/or support land swaps?

(ii) What are the carbon stocks in the area? What are the historical emission levels and how much emission can be avoided?

(iii) How profitable is the land use that causes emissions and hence what would be the opportunity costs of avoiding emissions?

(iv) What other environmental services are involved and could be enhanced to provide cobenefits to avoided forest conversion? Which stakeholders of such environmental services could be expected to co-invest?

(v) What alternative options for 'high $\mathrm{C}$ stock development' exist that could provide attractive local employment options? What resource-use rights do local communities claim to have on a formal and/or informal legal basis?

(vi) How is current repositioning of agents in the international value chain interacting with the options to provide positive economic incentives through REDD+ and achieve the national goals for emissions reduction set in the NAMA framework?

Questions $\mathrm{i}-\mathrm{V}$ will be answered on the basis of recent fieldwork in the Tripa area and extensive support by two NGOs-Yayasan Ekosistem Lestari (YEL) and PanEco-for local negotiations in the area since 2006, while question vi will be addressed in the discussion.

\section{Material and methods}

\subsection{Location}

The western coast of Aceh province, a strip 5-30 km-wide between the Indian Ocean and the mountains of the Bukit Barisan range that runs the length of Sumatra Island, has been a backwater of development throughout history. About a quarter (26\%) of its soils are histosols and $16 \%$ of its area is classified as protection or "conservation" forest, $6 \%$ as production forest and the rest as other land uses, although the latter category can include logged-over and primary forests. The area does not have easy access to its mountainous hinterland and has in Meulaboh a port of limited importance.

The Tripa swamp (Ruysschaert et al. 2009) is shared between two administrative districts: Nagan Raya and Aceh Barat Daya (Fig. 1). Tripa comprises a total area of 102,000 ha, which 
includes 62,000 ha of peat swamp within the boundaries of the Leuser Ecosystem (a National Strategic area for its biodiversity and water catchment values), and an additional $5 \mathrm{~km}$-wide surrounding buffer area. Tripa is adjacent to the Gunung Leuser National Park, which is part of a UNESCO World Heritage site. The Tripa peat swamp consists of three separate peat domes (Wahyunto et al. 2003).

The area is one of only three significant tracts of coastal peat-swamp forests (Tripa, Kluet, Singkil) remaining on the entire western coast of Sumatra Island and Aceh Province; there is hardly any peat swamp on the eastern coast of Aceh. These peat swamps are distinct from the remaining swamp forests on Sumatra's eastern coast and therefore hold a unique biodiversity value (YEL/PanEco 2010), which is the primary reason why the three are integral parts of the Leuser Ecosystem. Tripa also forms one of three remaining natural ecological corridors linking the Indian Ocean to the mountainous interior of the Leuser Ecosystem and the Gunung Leuser National Park. The area has been identified as a high-priority conservation area for maintaining floristic diversity (Laumonier et al. 2010). As a habitat of the Sumatran orangutan (Pongo abelii; the International Union for Conservation of Nature (IUCN) Red List classification of Critically Endangered), it harbours the highest known current density of orangutans in the world. It also supports Sumatran tigers (Panthera tigris sumatrae; IUCN Red List classification of Critically Endangered). In addition, the existence of Tripa and the other swamps is crucial for the survival of numerous specialist animal species. Otter civets (Cynogale bennetti), Storms' stork (Ciconia stormii), the white-winged wood duck (Cairina scutulata) and the masked finfoot (Heliopais personata) are especially noteworthy and restricted to swamp habitats (YEL/PanEco 2008). The habitats are also important for aquatic and marine species, including the saltwater crocodile (Crocodylus porosus) and several marine

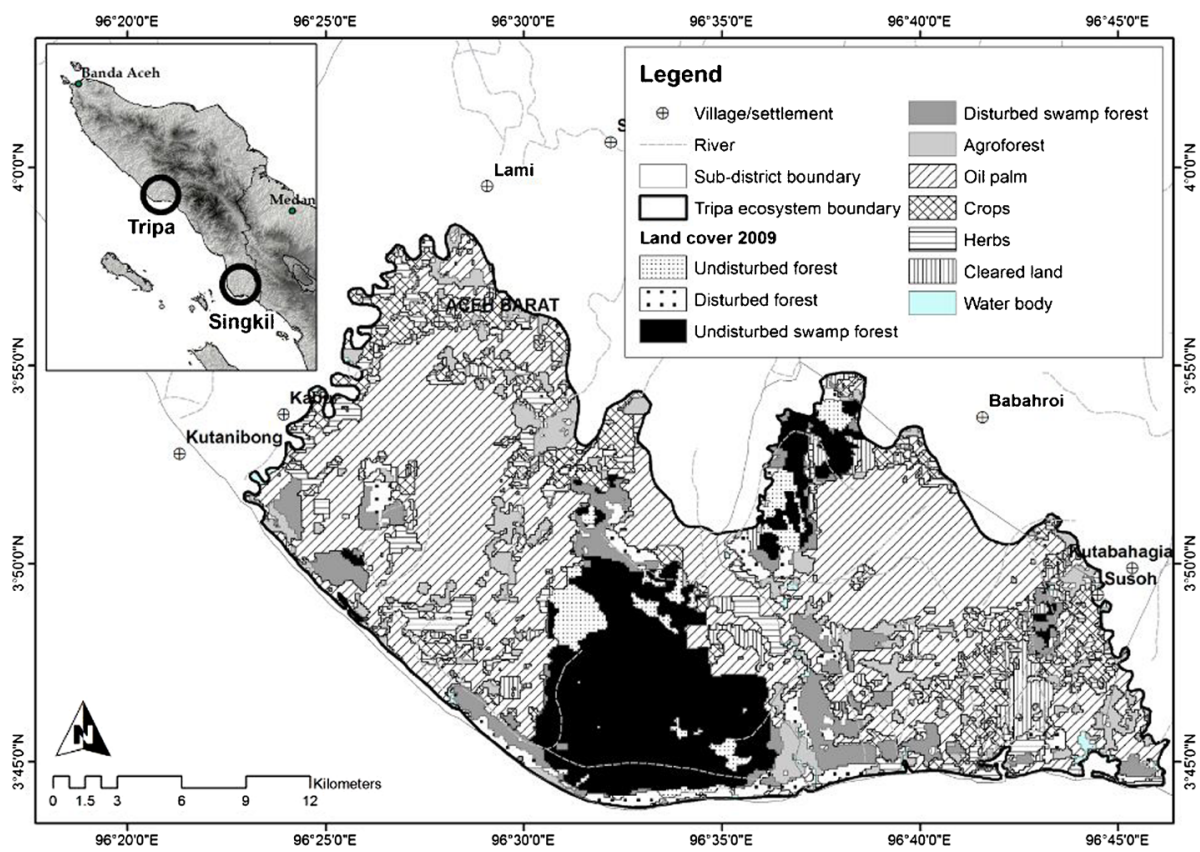

Fig. 1 Location of the Tripa swamp on the western coast of Aceh at the northern end of Sumatra Island, Indonesia 
turtle species that nest on the adjacent beaches. Most of the species mentioned appear on the IUCN Red List of Threatened Species.

\subsection{Land-use history and rights}

Methods akin to participatory rural appraisal and the Rapid Land Tenure Assessment were used to identify local perspectives on the landscape, land-use patterns in their historical context and the potential presence of conflicts over land tenure (Galudra et al. 2010). Existing spatial data sets on administrative boundaries, concessions and land cover (Minnemeyer et al. 2008) were combined. Earlier results from YEL/PanEco (2008, 2010) were cross-checked in focus-group discussions in villages and interviews with local government and NGO staff.

\subsection{Economic benefits of land-use options}

The main land-use systems in the area were characterized in the agricultural calendar, labour requirements for different phases of the system, use of external inputs and yield levels. Socio-economic analyses were conducted through three steps: (i) identification of land uses and land-use changes and relationships with livelihoods' patterns, including selection of villages for in-depth study; (ii) identification of current community livelihoods and dependency on forest and peat-swamp ecosystems; and (iii) assessment of income and expenses. A spreadsheet input/output accounting model was used to derive Net Present Value (USD ha ${ }^{-1}$ ) as sum of discounted future cash flows at a discount rate of $6.5 \%$ year $^{-1}$ when standard labour costs are used; it allowed expression as returns to labour by modifying labour costs until NPV was zero (Tomich et al. 2001; White et al. 2010). Further details are provided in Tata et al. (2010).

Five villages - Babah Lhueng, Kuala Seumayam, Makarti Jaya, Ladang Baru and Ie Mameh - were selected based on location and the history of the village. In-depth study was conducted in all five, while household surveys were focused on Babah Lhueng and Ladang Baru in Nagan Raya district, and Ie Mameh in Aceh Barat Daya district.

\subsection{Carbon-stock assessment}

Carbon stocks were assessed using the Rapid Carbon Stock Appraisal (RaCSA), which required two types of data: (i) area of changes; and (ii) trajectories of land-use systems. Data on area of changes of land-use systems were produced by Analysis of Land Use and Cover Trajectory (ALUCT; Hairiah et al. 2011). In RaCSA, emission and sequestration factors for a pair of land-use systems within a time period are defined as the stock differences between initial and subsequent land-use systems per unit area. Sequestration is defined as increase of the aboveground C stocks, while "emission" is decrease. Net emission/net sequestration is an estimate obtained by deducting sequestration from the emission in a given area and period of time (Hairiah et al. 2011). This was conducted on the basis of a time series of land-cover maps derived from satellite images. Scene P130-R057 was sampled from Landsat 5 Thematic Mapper of 6 January 1990, a Landsat Composite $(3,4,5)$ from 1995, and Landsat 7 Enhanced Thematic Mapper of 24 August 2001, 8 February 2005 and 24 April 2009; details are provided by Tata et al. (2010).

Time-averaged carbon stocks are obtained from measurements at different stages of a systems' life cycle. Five C pools must be assessed, according to the United Nations Intergovernmental Panel on Climate Change (IPCC 2006): aboveground biomass (tree and 
understorey), dead wood, surface litter (necromass) and belowground biomass (roots) and necromass (soil organic $\mathrm{C}$ and peat). The sampling method used in this survey refers to the ASB protocol (Hairiah et al. 2011). Three nested sub-plots were established in each sample plot depending on vegetation: $40 \times 5 \mathrm{~m}$ sub-plot for counting trees and dead wood between 5 and $30 \mathrm{~cm}$ diameter; $100 \times 20 \mathrm{~m}$ plots for measuring trees and dead wood of more than $30 \mathrm{~cm}$ diameter; quadrant of $2 \times 0.5 \times 0.5 \mathrm{~m}$ set up inside the sub-plot used to count understorey, litter and soil. A total of 23 plots were measured in undisturbed peat forest, disturbed peat forest, disturbed forest of Tripa and agroforests in peat. We analysed data collected by the World Agroforestry Centre from nine plots in 2010 (Tata et al. 2010) and data from 14 plots studied by van Belle and Hennin (2008). Peat depth, classification, bulk density and carbon content were estimated from a previous study in the area (Agus and Wahdini 2008).

\subsection{Opportunity-cost curves}

The opportunity costs of avoided emissions (or "abatement costs") are estimated from the increase in profitability of land use that was achieved in a certain landscape over a certain time period, expressed per unit of emission of carbon dioxide (or its equivalent in the form of other greenhouse gases). Opportunity costs (OpCost) where first calculated for every pixel (or map unit) that had changed land cover over a time step, using the typical $\mathrm{C}$ stocks $\left(\mathrm{Mg} \mathrm{C} \mathrm{ha}{ }^{-1}\right)$ and Net Present Value (USD ha ${ }^{-1}$ ) of each land-use type distinguished (Swallow et al. 2007).

$$
\text { OpCost }=\Delta_{t=>t+1}(N P V) /\left(a \Delta_{t=>t+1}(\text { Cstock })\right), \text { in }\left[\text { USD } \mathrm{Mg} \mathrm{CO}_{2} \mathrm{e}^{-1}\right]
$$

where: $\Delta_{t=t_{+}+l}($ ) indicates a change of parameter value over the time period t to $t+1, N P V$ is Net Present Value or discounted sum of cash flow over assessment period (in USD ha ${ }^{-1}$ ), Cstock is the time-averaged carbon stock of the land-use system (in $\mathrm{Mg} \mathrm{C} \mathrm{ha}^{-1}$ ) and $a$ denotes the conversion factor from carbon to $\mathrm{CO}_{2} \mathrm{e}(=44 / 12)$.

The frequency distribution of these OpCost values, expressed against the average emissions from the landscape was calculated as an "OpCost curve", using a land-use change matrix as well as the OpCost value for any type of land-use change. The ABACUS tool developed by the ALLREDDI project (Harja et al. 2012; http:// worldagroforestrycentre.org/regions/southeast_asia/resources/redd-abacus-sp) was used to generate such cumulative OpCost curves.

\subsection{Alternative options for "high C stock development"}

Dynamic land-use change scenarios were developed using the Forest, Agroforest, Low-value Landscape Or Wasteland? (FALLOW) model (van Noordwijk 2002; van Noordwijk et al. 2008; Suyamto et al. 2009), which represents farmers' decisionmaking among land-use systems and labour allocation on the basis of learning from the performance of such land-use systems in the local context. Mulia et al. (2013) in this issue describe the model in more detail in the context of an application for the peat swamps on Sumatra's eastern coast. Five scenarios were developed for Tripa: (i) business as usual (BAU), where oil-palm estates operate according to current oil-palm concession rules and have a right to open remaining forests inside their concession; (ii) conservation of remaining forests (patch); (iii) instantaneous restoration of all oilpalm plantations into forest ("instantaneous"); (iv) gradual restoration (gradual); and (v) establishment of two corridors to support orangutan preservation (corridor). 
Results can be expressed as changes in total landscape carbon stock and farmers' income. The parameterization was derived from earlier applications of the model to Aceh's western coast (Lusiana et al. 2011).

\section{Results}

\subsection{Land-use history and the formal basis of the companies' rights (Q i)}

During the colonial period, some rubber and oil-palm plantations were established around the peat-swamp forest of Tripa, relying on road transport to the city of Medan in North Sumatra province. According to local history recounted by stakeholders, not much happened in the peat swamp itself beyond providing some livelihoods (e.g. fishery, timber, plants) and protecting people from extreme events (e.g. water regulation, watershed protection), before transmigration programs opened up this area in the 1990s. Large oil-palm concessions began converting the peat-swamp forest. This oil-palm expansion period ended in 1997-98 during a phase of intensified conflict between the Acehnese independence movement and the national government. Most of the transmigrant population left the area and natural ecological restoration started in abandoned oil-palm plantations (Table 1). According to a Consensus Forest Land Use Plan (Tata Guna Hutan Kesepakatan or TGHK) (Ministry of Forestry and Estate Crops 1998), the legal status of Tripa was "other uses [non-forest] area" (Area Penggunaan Lain or APL). However, in 1985, the first legal right for oil-palm establishment

Table 1 Brief history of land use in Tripa ecosystem (further details in Tata et al. 2010)

\begin{tabular}{|c|c|c|c|}
\hline \multicolumn{2}{|l|}{ Period } & \multirow{2}{*}{$\begin{array}{l}\text { Description } \\
\text { Introduction of plantation crops such } \\
\text { as oil palm (in Sukaraja), cocoa } \\
\text { (in Seunaam, Seumayam } \\
\text { settlement area) and rubber (Babah } \\
\text { Leung and Ladang Baru area) } \\
\text { outside the peat swamp }\end{array}$} & \multirow{2}{*}{$\begin{array}{l}\text { Livelihoods changes } \\
\text { From swidden agriculture, } \\
\text { people became more } \\
\text { involved in oil-palm } \\
\text { plantations }\end{array}$} \\
\hline $1930 \mathrm{~s}$ & $\begin{array}{l}\text { Plantations established by } \\
\text { Dutch colonial } \\
\text { government (rubber } \\
\text { and oil palm) }\end{array}$ & & \\
\hline $1991-8$ & $\begin{array}{l}\text { Transmigration program } \\
\text { Degazettement of forests } \\
\text { for oil-palm } \\
\text { plantations }\end{array}$ & $\begin{array}{l}\text { SP } 1,2 \text { and } 3 \text { in Seunaam, along } \\
\text { with oil-palm expansion } \\
\text { Five oil-palm concessions granted } \\
\text { and established on peatland }\end{array}$ & $\begin{array}{l}\text { Oil-palm expansion } \\
\text { Citrus (Citrus sinensis) } \\
\text { production in some } \\
\text { transmigration areas (in } \\
\text { particular, Seunaam 4) }\end{array}$ \\
\hline 1998-2004 & $\begin{array}{l}\text { Ecological recovery } \\
\text { during heightened } \\
\text { military conflict }\end{array}$ & $\begin{array}{l}\text { Farming activity decreases } \\
\text { significantly }\end{array}$ & $\begin{array}{l}\text { Frequency of farmers } \\
\text { accessing forest and farm } \\
\text { areas decreases owing to } \\
\text { safety issues }\end{array}$ \\
\hline 2005 & $\begin{array}{l}\text { Tsunami (Dec. 2004) } \\
\text { rebuilding program, } \\
\text { peace agreement }\end{array}$ & $\begin{array}{l}\text { Natural forest opening movement: } \\
\text { wood extraction }\end{array}$ & $\begin{array}{l}\text { People involved in logging to } \\
\text { obtain raw materials for } \\
\text { tsunami rebuilding program }\end{array}$ \\
\hline 2008 & $\begin{array}{l}\text { End of rebuilding period, } \\
\text { oil-palm plantations } \\
\text { expand }\end{array}$ & $\begin{array}{l}\text { Land conversion to plantations } \\
\text { (oil palm) increases }\end{array}$ & $\begin{array}{l}\text { People return to farming; some } \\
\text { move to off-farm activities } \\
\text { such as oil-palm harvesting }\end{array}$ \\
\hline 2008-09 & $\begin{array}{l}\text { 'One million oil palms' } \\
\text { program in Nagan } \\
\text { Raya and Aceh Barat } \\
\text { Daya }\end{array}$ & $\begin{array}{l}\text { Land conversion to plantations } \\
\text { (oil palm) increases }\end{array}$ & \\
\hline
\end{tabular}


was granted to the company, PT Kallista Alam, based on decree no. SK.26/HGU/DA/85. During the '80s and '90s, five concession permits were issued that covered all of Tripa (YEL/PanEco 2008).

The tsunami of 26 December 2004 caused substantial damage to lives and property on the western coast of Aceh (Bayas et al. 2011) although in Tripa only the communities adjacent were affected. All the communities further inland were effectively protected owing to the efficient buffering action of Tripa itself. The tsunami induced an intensive process of negotiations between the two sides of the conflict and a comprehensive peace agreement in 2005 cleared the way for new economic development. It also restarted the clearing of Tripa's forest.

The two administrative districts that share the Tripa swamp have followed different landuse and development policies. In Nagan Raya, west of the Seumayam River, expansion of oilpalm plantations has been fast, promoted by the district government. Under the program Nagan Sejuta Sawit (One Million Oil Palms in Nagan), approximately 200,000 oil-palm seedlings were distributed to local communities in 2009. Despite an official commitment by the district government to protect the peat-swamp forest, conversion to oil-palm plantations was rapid within concession area covering the Tripa peat swamp. Large oil-palm companies re-started their operations using their existing rights to rehabilitate the abandoned oil-palm concession areas and to convert the remaining peat forests into oil palm. An additional, large, oil-palm concession area was established. Obtaining their concession rights from the government, the three main oil-palm companies nevertheless encountered conflict over land with local communities that had customary-rights claims. Sometimes violent, these conflicts lead to a joint petition by the 21 villages in and around Tripa, requesting the government to assist them to regain control over the area, to manage it sustainably and to conserve the approximately 20,000 ha of primary forest that remained.

In Aceh Barat Daya, which straddles the Seumayam River east-west, the district government also had a 1 million oil-palms program but it focussed on support to smallholders through a so-called "special autonomy fund", providing planting materials and fertilizers. In addition, the district government took over the main abandoned oil-palm concession (8492 ha) and ruled that community members could establish oil-palm plots of up to 2 ha per household. A second, large, oil-palm concession is only partly operating and not expanding. Along the Seumayam River, however, a new, large ( $2740 \mathrm{ha}$ ) oil-palm concession has been established on the Aceh Barat Daya side. In addition to these large concession areas, oil-palm smallholdings are also expanding, converting the remaining forest outside the concession areas.

Across the two districts, the large oil-palm plantations currently hold about $80 \%$ of the Tripa peat swamp (Fig. 2). However, the richest smallholders from the local villages are increasingly driving land-use change in Tripa, expanding into the remaining forest between the large oil-palm concessions, with active support (through subsidies and policies) from the district governments. The official stance from village leaders to save Tripa does not stop its destruction by local people nor by plantation companies.

However, awareness of the protection that the forest had provided during the tsunami (Cochard et al. 2008; Bayas et al. 2011) plus new evidence of the area's biodiversity values, initiated actions by local and international NGOs to conserve the remaining forest. In addition, the carbon emissions from conversion of peat-swamp forest to oil palm became an issue of international concern but also, more specifically, in Aceh Province. The governor of Aceh, elected after the political reconciliation, has been promoting "Green Aceh" to obtain access to carbon finance. Tripa has the highest emission rates in the province. As such, the Aceh Province declared in 2007 a moratorium on forest conversion and established a team to review 


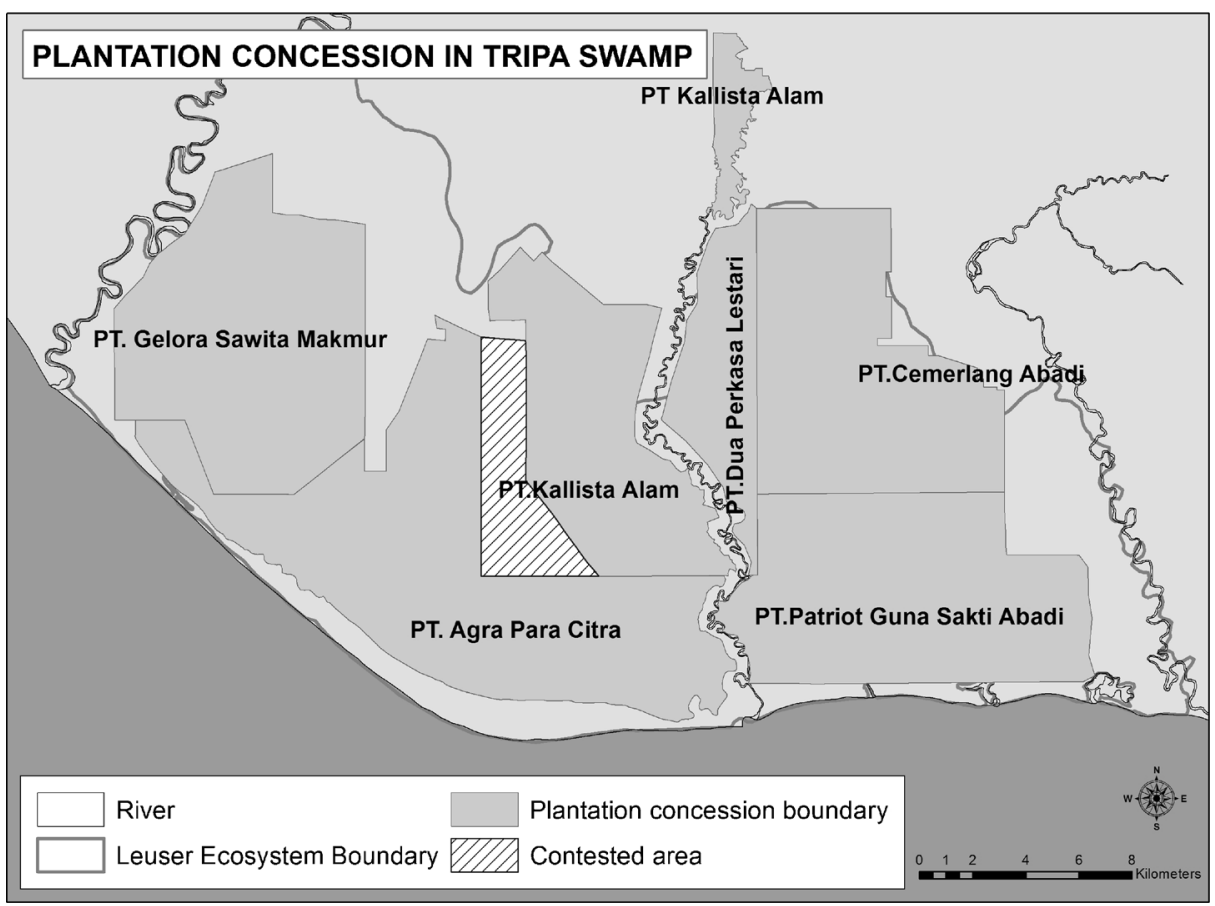

Fig. 2 Oil-palm concession areas within the Tripa (former, in 2010) peat-swamp forest (62,000 ha). The hatched area is the focus of a current contest as a permit was issued despite the area's inclusion in the national moratorium on forest clearing

the legality of all type of concessions (e.g. over forests and agricultural land). In its 2010 spatial plan presented to the Indonesian Ministry of Forestry, the Aceh Government included Tripa as a conservation area to be protected, however, it remains listed as APL.

Options to cancel large concessions seem, however, difficult because their owners hold a legal document from a central government ministry, something the local villagers with customary claims do not possess. Options to swap existing oil-palm concession areas in Tripa with degraded land is possible as there are at least 200,000 ha of such land in Aceh (Aceh Green 2008). But, this land is divided into areas of only a few hundred hectares each. In addition, these lands have unclear legal status, which makes investment unattractive, technically more costly and socially risky (Ruysschaert et al. 2011).

The concession area with the best remaining forests was, in 2010, in the holding of a large oil-palm company, which had close business relationships with prominent members of the Roundtable for Sustainable Palm Oil (RSPO). The RSPO had passed a resolution to protect Tripa. The parent company was also the target of a public campaign in Europe against conversion (The Independent 2009). As such, the company was aware of the public protests against conversion and initially declared an internal moratorium. But, in late 2010, it sold the concession to a company operating on the domestic market and not bound by RSPO rules.

In May 2011, parts of the Tripa swamp were included in the map of the two-year moratorium on new permits to convert primary forests or peatlands. In August 2011, however, the governor of Aceh signed a new permit for PT Kallista Alam to clear 1605 ha outside its original permit area for oil-palm plantations. This land was 
supposedly protected by the moratorium. Public protests, a response from the central government and a court case initiated by an environmental NGO were pending at the end of 2011. At the time of writing in early 2013, the case is still before the court. There are also other two cases, brought by the Ministry of Environment (i.e. not an NGO), against PT Kallista Alam and PT Surya Panen Subur 2.

3.2 Carbon stocks, historical emission levels and potential emissions that can be avoided (Q ii)

Natural forest cover in Tripa declined from $54 \%$ in 1995 to $18 \%$ in 2009. Oil palm, in either large plantations or smallholdings, increased by $36 \%$ while annual crops and agroforests remained constant. Three types of forests could be distinguished: (i) primary forest of high density; (ii) primary forest of low density; and (iii) secondary forest, which consisted of regenerated vegetation and forest burnt in 1996. Average aboveground carbon density in each type of forest was $193 \mathrm{Mg} \mathrm{ha}^{-1}$ for undisturbed peat forest, $84 \mathrm{Mg} \mathrm{ha}^{-1}$ for disturbed peat forest, $112 \mathrm{Mg} \mathrm{ha}^{-1}$ for disturbed forest and $28.5 \mathrm{Mg} \mathrm{ha}^{-1}$ for agroforest on peat, respectively. Distribution of $\mathrm{C}$ stocks in each land-use type was described as a cumulative frequency graph, which suggests approximate normality of data distribution (Fig. 3).

The peat carbon density in Tripa, as a product of bulk density and carbon concentration in dry matter, was measured to be $419 \mathrm{Mg} \mathrm{Cha}^{-1}$ per metre of peat, resulting in carbon stocks for the whole profile that ranged from $382 \mathrm{Mg} \mathrm{ha}^{-1}$ for a $130 \mathrm{~cm}$ depth profile to $2240 \mathrm{Mg} \mathrm{ha}^{-1}$ for a location with a depth of $390 \mathrm{~cm}$ (Agus and Wahdini 2008). Based on current data, peat domes in Tripa are estimated to have an average depth of $3.2 \mathrm{~m}$ and $1350 \mathrm{Mg} \mathrm{ha}^{-1}$ as average belowground carbon stock. No site-specific estimates of the emissions from conversion are available but the low-density peat leads to rapid subsidence after drainage, as is evident from root exposure on remnant tree stumps.

At landscape level, the average aboveground C-stock density in the $1020 \mathrm{~km}^{2}$ assessed in Tripa decreased from $148 \mathrm{Mg} \mathrm{ha}^{-1}$ in 1990 to $61 \mathrm{Mg} \mathrm{ha}^{-1}$ in 2009 while for the $480 \mathrm{~km}^{2}$ subset of this that is conceded to oil-palm plantations, carbon density decreased from $114 \mathrm{Mg} \mathrm{ha}^{-1}$ in 1990 to $48 \mathrm{Mg} \mathrm{ha}^{-1}$ in 2009.

Although the burning of peatlands is forbidden by Indonesian law, 575 fires were recorded by satellite (fire hotspots of at least $20 \times 20 \mathrm{~m}^{2}$ ) in the Tripa peat swamp alone between November 2002 and February 2011 (NASA/University of Maryland 2002) (Fig. 4).

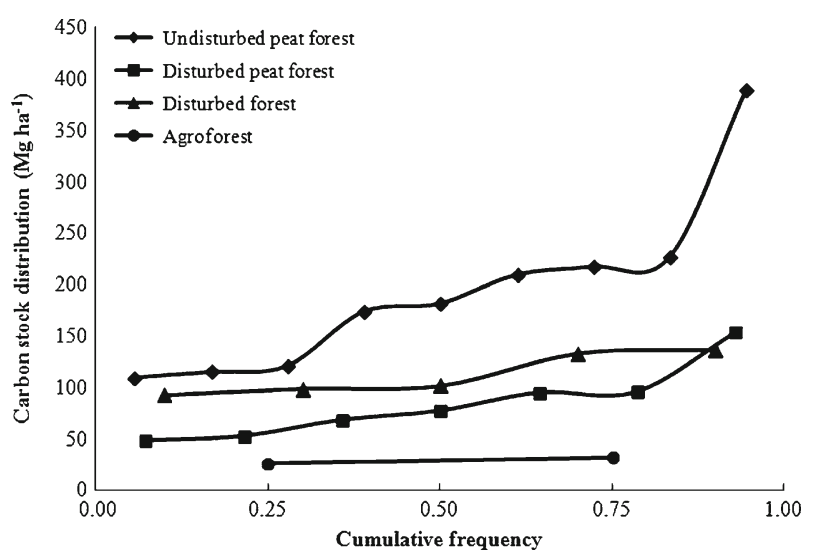

Fig. 3 Cumulative frequency of aboveground carbon stock based on land-cover classifications in the Tripa area 
Fire Events in Tripa and Plantations

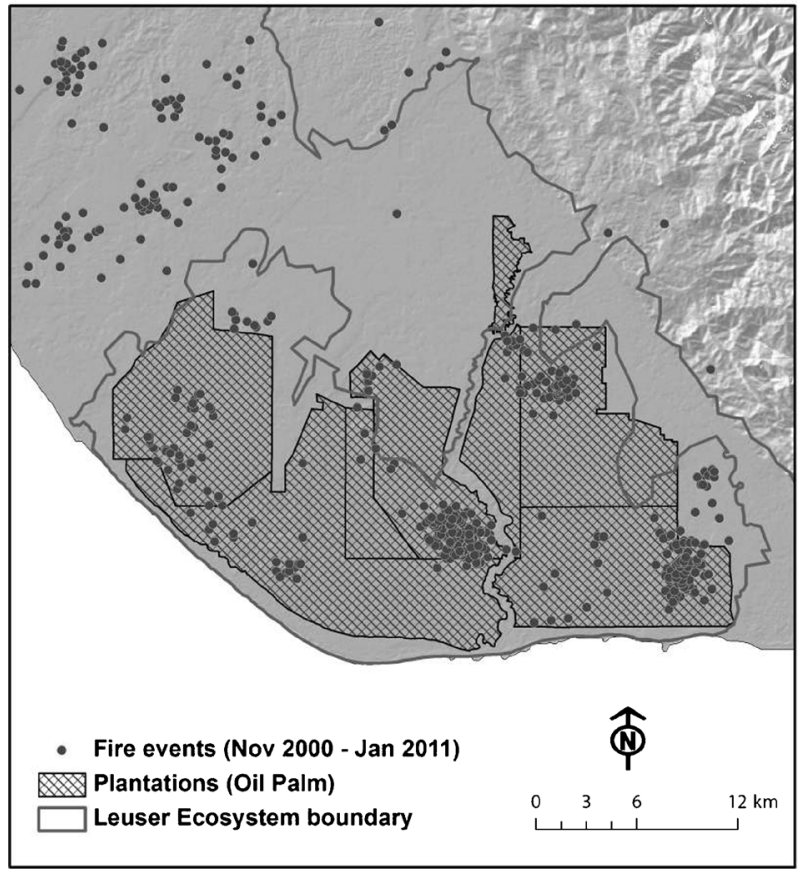

Fig. 4 Fire events recorded in Tripa ("hot spot" data derived from NASA/University of Maryland)

Annual aboveground emission rates owing to land-use conversion in the study area ranged between $0.94 \mathrm{Tg} \mathrm{CO}_{2} \mathrm{e}$ year ${ }^{-1}$ and $2.2 \mathrm{Tg} \mathrm{CO}_{2} \mathrm{e}$ year ${ }^{-1}$, with the highest value in the period 1990-1995 when conversion of forest to oil-palm plantations peaked (Table 2). The lowest rate, during 2001-2005, was because of a slowdown of activities during the conflict. The posttsunami peace agreement lead to an increase in emissions. Over the whole observation period, average annual emissions were $14.45 \mathrm{Mg} \mathrm{CO}_{2} \mathrm{e} \mathrm{ha}^{-1}$ year $^{-1}$.

3.3 Economic benefits of land-use options and the opportunity costs of avoiding emissions (Q iii)

Results of a livelihoods and economic analysis confirmed oil palm as the driver of the local economy. Gross incomes of IDR 600,000-1,500,000 (approximately USD 67-168) per month per hectare were reported by smallholders with oil palm. In 2010, prices for fresh fruit bunches fluctuated IDR 700,000-1,050,000 (approximately USD 80-110) per Mg (Tables 3 and 4).

Employment by oil-palm companies provides or supplements livelihoods for many households. Two types of work were distinguished.

(i) Contract labourers, ranging from 'buruh syarat kerja umum' (SKU) contracts for middlelevel positions to short-term contracts for unskilled labour usually brought in from outside, typically from Java Island (hence the local term 'contract Javanese' or JAKON). Within the surveyed villages, this labour force was dominated by Javanese and Sundanese housed inside the plantation. Some were transmigrants or their descendants who had not had success in farming their own plots. 
Table 2 Emissions, sequestration and net emissions from 1990 to 2009, based on aboveground carbon-stock changes within the Leuser Ecosystem Zone (Kawasan Ekosistem Leuser or KEL) boundaries and the Tripa study area, which includes a $5 \mathrm{~km}$ zone around KEL

\begin{tabular}{|c|c|c|c|c|}
\hline Year & 1990-1995 & 1995-2001 & 2001-2005 & $2005-2009$ \\
\hline \multicolumn{5}{|l|}{ Emissions: Study area } \\
\hline Total emissions $\left(\mathrm{Tg} \mathrm{CO}_{2} \mathrm{e}\right)$ & 11.008417 & 9.310972 & 3.775111 & 7.591064 \\
\hline Annual emissions $\left(\mathrm{Tg} \mathrm{CO}_{2}\right.$ e year $\left.{ }^{-1}\right)$ & 2.201683 & 1.551829 & 0.943778 & 1.897766 \\
\hline Ave. ann. emissions $\left(\mathrm{Mg} \mathrm{CO}_{2} \mathrm{e} \mathrm{ha}^{-1}\right.$ year $\left.^{-1}\right)$ & 21.58 & 15.21 & 9.25 & 18.60 \\
\hline \multicolumn{5}{|l|}{ Sequestration: Study area } \\
\hline Total sequestration $\left(\mathrm{Tg} \mathrm{CO}_{2} \mathrm{e}\right)$ & 0.929925 & 1.057174 & 0.740446 & 1.652640 \\
\hline Annual sequestration $\left(\mathrm{Tg} \mathrm{CO}_{2} \mathrm{e}\right.$ year $\left.^{-1}\right)$ & 0.185985 & 0.176196 & 0.185112 & 0.413160 \\
\hline Ave. ann. sequestration $\left(\mathrm{Mg} \mathrm{CO}_{2} \mathrm{e} \mathrm{ha}^{-1}\right.$ year $\left.^{-1}\right)$ & 1.82 & 1.73 & 1.81 & 4.05 \\
\hline \multicolumn{5}{|l|}{ Net emissions: Study area } \\
\hline Total net emissions $\left(\mathrm{Tg} \mathrm{CO}_{2} \mathrm{e}\right)$ & 10.078492 & 8.253798 & 3.034664 & 5.938424 \\
\hline Annual net emissions $\left(\mathrm{Tg} \mathrm{CO}_{2} \mathrm{e}_{\text {year }}^{-1}\right)$ & 2.015698 & 1.375633 & 0.758666 & 1.484606 \\
\hline Ave. ann. net emissions $\left(\mathrm{Mg} \mathrm{CO}_{2} \mathrm{e} \mathrm{ha}^{-1}\right.$ year $\left.^{-1}\right)$ & 19.75 & 13.48 & 7.43 & 14.55 \\
\hline \multicolumn{5}{|l|}{ Emissions: KEL } \\
\hline Total emissions $\left(\mathrm{Tg} \mathrm{CO}_{2} \mathrm{e}\right)$ & 7.169491 & 7.177397 & 2.353612 & 5.252623 \\
\hline Annual emissions $\left(\mathrm{Tg} \mathrm{CO}_{2} \mathrm{e}\right.$ year $\left.{ }^{-1}\right)$ & 1.433898 & 1.196233 & 0.588403 & 1.313156 \\
\hline Ave. ann. emissions $\left(\mathrm{Mg} \mathrm{CO}_{2} \mathrm{e} \mathrm{ha}^{-1}\right.$ year $\left.^{-1}\right)$ & 23.77 & 19.83 & 9.76 & 21.77 \\
\hline \multicolumn{5}{|l|}{ Sequestration: KEL } \\
\hline Total sequestration $\left(\mathrm{Tg} \mathrm{CO}_{2} \mathrm{e}\right)$ & 0.181525 & 0.642028 & 0.343573 & 0.641864 \\
\hline Annual sequestration $\left(\mathrm{Tg} \mathrm{CO}_{2} \mathrm{e}\right.$ year $\left.{ }^{-1}\right)$ & 0.036305 & 0.107005 & 0.085893 & 0.160466 \\
\hline Ave. ann. sequestration $\left(\mathrm{Mg} \mathrm{CO}_{2} \mathrm{e} \mathrm{ha}^{-1}\right.$ year $\left.^{-1}\right)$ & 0.60 & 1.77 & 1.42 & 2.66 \\
\hline \multicolumn{5}{|l|}{ Net emission: KEL } \\
\hline Total net emissions $\left(\mathrm{Tg} \mathrm{CO}_{2} \mathrm{e}\right)$ & 6.987965 & 6.535369 & 2.010039 & 4.610759 \\
\hline Annual net aboveground emissions $\left(\mathrm{Tg} \mathrm{CO}_{2} \mathrm{e}\right.$ year $\left.{ }^{-1}\right)$ & 1.397593 & 1.089228 & 0.502510 & 1.152690 \\
\hline Ave. ann. net emissions $\left(\mathrm{Mg} \mathrm{CO}_{2} \mathrm{e} \mathrm{ha}^{-1}\right.$ year $\left.^{-1}\right)$ & 23.17 & 18.06 & 8.33 & 19.11 \\
\hline
\end{tabular}

(ii) Daily wage labourers, for tasks such as fertilizer, pesticide and herbicide application, weeding and collecting ripe fruit bunches (mostly women) or building and repairing roads, drainage systems and bridges (mostly men). Wage rates of USD 2.80-4.45 per day were reported for such work, with labourers usually recruited from the surrounding villages.

Table 3 Monthly household income by occupation

\begin{tabular}{lcccrr}
\hline Occupation & \multicolumn{2}{l}{ Household sample } & $\begin{array}{l}\text { Range of income } \\
\text { per month (IDR 000) }\end{array}$ & $\begin{array}{l}\text { Median (IDR } \\
\text { 000 } \text { month }^{-1} \text { ) }\end{array}$ & $\begin{array}{r}\text { Standard } \\
\text { deviation }\end{array}$ \\
\cline { 2 - 3 } & $\mathrm{N}$ & $\%$ & & & \\
\hline Fishing & 10 & 14.29 & $115-750$ & 199 & 111 \\
Agriculture & 32 & 45.71 & $108-486$ & 167 & 126 \\
Mixed garden & 32 & 45.71 & $30-3000$ & 125 & 526 \\
Smallholding oil palm & 12 & 17.14 & $160-5500$ & 1233 & 2045 \\
Non-farm: oil-palm workers & 31 & 44.29 & $120-2800$ & 450 & 585 \\
\hline
\end{tabular}


Table 4 Return to labour and land per land-use system in Tripa

\begin{tabular}{|c|c|c|c|}
\hline Land-use system & $\begin{array}{l}\text { Return to labour } \\
\left(\text { IDR } \mathrm{pd}^{-1}\right)\end{array}$ & $\begin{array}{l}\text { Return to land } \\
\text { (IDR } 000 \mathrm{ha}^{-1} \text { ) }\end{array}$ & $\begin{array}{l}\text { Labour requirement } \\
\left(\mathrm{pd} \mathrm{ha}^{-1} \text { year }^{-1}\right)\end{array}$ \\
\hline Cocoa agroforestry & 46,934 & 20,521 & 93 \\
\hline Smallholding oil palm & 139,881 & 88,134 & 57 \\
\hline Home garden & 56,804 & 5972 & 77 \\
\hline Irrigated rice paddy & 32,433 & 2229 & 73 \\
\hline
\end{tabular}

Figures based on 2010 prices and expressed in June 2010 rupiah (Rp $9199=$ USD 1). $p d$ person day

Native Acehnese showed that they were not interested in working for oil-palm companies as contract labour because they mostly had their own farms. Working as daily wage labourers was not adopted as part of their culture because the oil-palm companies took over land they considered their own. However, to obtain quick cash they would work as daily wage labourers in their spare time. Smallholders and local entrepreneurs also employed extra labour for harvesting, either on a daily pay basis or through a profit-share system.

When comparing carbon stock and profitability, four groups of land use can be identified in Tripa (Fig. 5): (i) high carbon and low profitability (e.g., forest); (ii) medium carbon and medium profitability (e.g., logging and agroforest); (iii) low-carbon stock and low-to-medium profitability (e.g., annual crops and agroforest); and iv) low-carbon stock and high profitability (e.g., oil palm).

The slope of the line connecting natural forest (group 1) to oil palm (group 4) represents the opportunity cost of avoiding such emissions (or 'abatement costs') at slightly over 10 USD Mg $\mathrm{CO}_{2} \mathrm{e}^{-1}$. If such a conversion is a staged process, the opportunity costs of converting natural forest and natural, peat-swamp forest to other land uses (groups 2 or 3 ) are higher while that of converting other land uses (groups 2 or 3) to oil-palm plantations is lower. By taking into account emissions from peat during land-use conversion, the average emission in Tripa was estimated to be $20 \mathrm{Mg} \mathrm{CO}_{2} \mathrm{e} \mathrm{ha}^{-1}$ year $^{-1}$. This is made up of contributions from multiple conversion steps, which differ in their opportunity cost (Y axis) and total emissions in the landscape (X-axis) (Fig. 6).

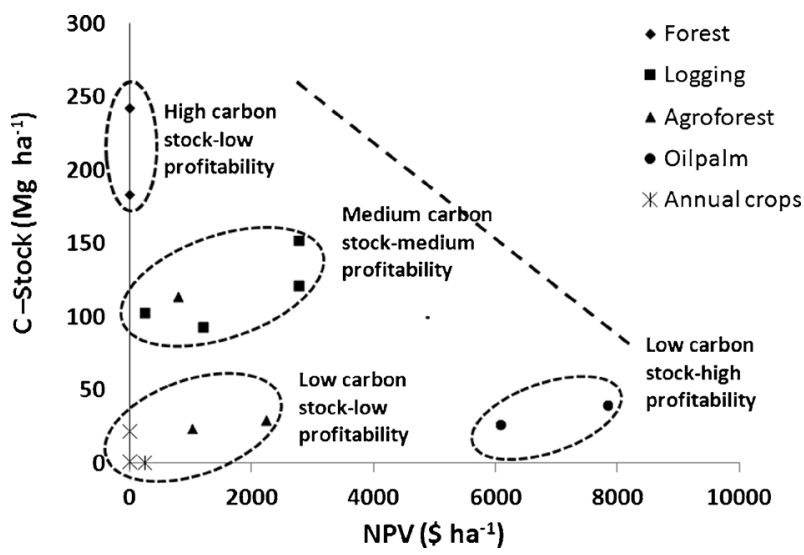

Fig. 5 Trade-off between profitability (net present value $=$ NPV) and typical carbon stock of the land-use systems encountered in Tripa 


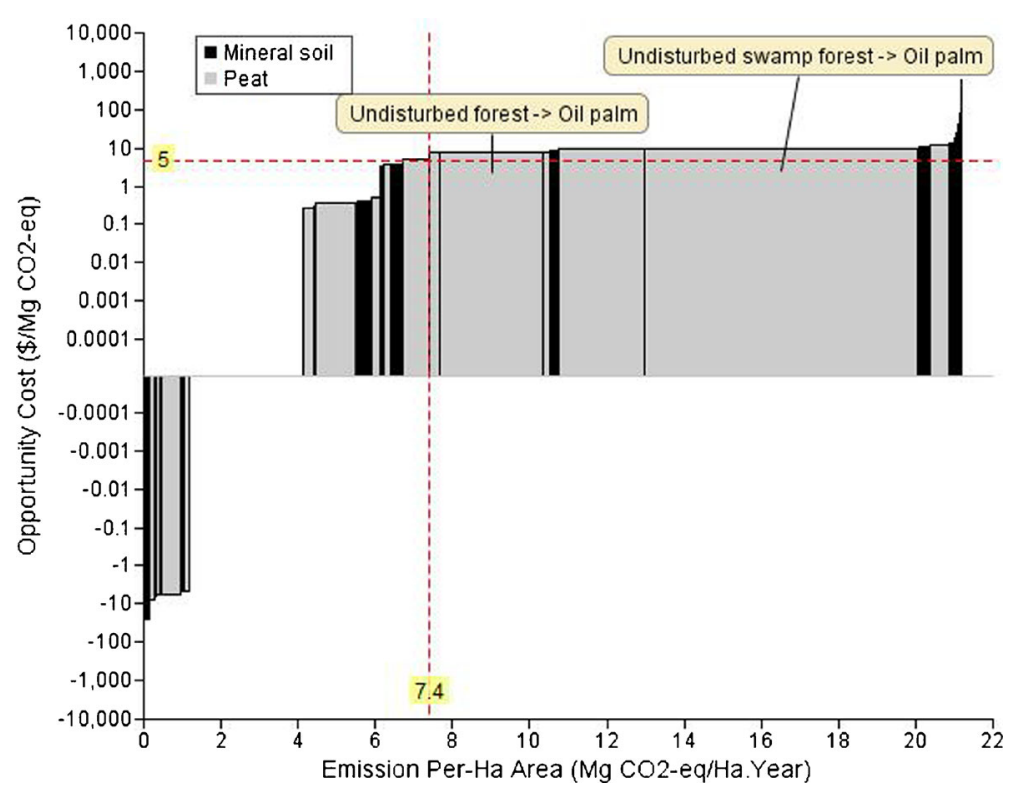

Fig. 6 Apparent opportunity- or abatement-cost curves for $\mathrm{CO}_{2}$ emissions of peat and mineral soil throughout the entire period of analysis (1994-2009) in Tripa

Using the threshold of 5 USD Mg CO $\mathrm{C}^{-1}$ (Stern 2007), the emissions from land-use conversion that could have been avoided ranged between $6 \mathrm{Mg} \mathrm{CO}_{2} \mathrm{e} \mathrm{ha}^{-1}$ year ${ }^{-1}$ to $15.3 \mathrm{Mg}$ $\mathrm{CO}_{2} \mathrm{e}$ ha $^{-1}$ year $^{-1}$ over different periods of observation. Approximately $41 \%$ of the aboveground carbon-stock emission, totalling $5.88 \mathrm{Mg} \mathrm{CO}_{2} \mathrm{e} \mathrm{ha}{ }^{-1}$ year $^{-1}$, could have been avoided if a carbon price of 5 USD $\mathrm{Mg} \mathrm{CO}_{2} \mathrm{e}$ applied only for aboveground losses and a lower fraction (35\%) but higher total amount $\left(7.03 \mathrm{Mg} \mathrm{CO}_{2} \mathrm{e} \mathrm{ha}^{-1}\right.$ year $\left.^{-1}\right)$ if belowground emissions from peatland conversion were taken into account.

\subsection{Biodiversity and environmental services (Q iv)}

A total of 92 tree species were identified in 23 plots (4.6 ha) in the Tripa area. In undisturbed peat forest (four plots), a total of 20 species were encountered, with an average of eight species in each plot. Secondary peat forest had less, with 11 species found in five plots with an average of five species per plot. The number of species in disturbed forest on mineral soils was higher: 79 species in 14 plots with an average of 12 species per plot. Eugenia jambos, Eugenia curtisii, Litsea cubeba and Laurus nobilis were the most common species in the Tripa area, dominating all types of forest. Ten dominant tree species found in Tripa (including E. jambos as most common species) were identified as sources of orangutan food by Russon et al. (2007).

Beyond biodiversity and $\mathrm{C}$ values as global goods, Tripa also provides crucial environmental services to the local economy through opportunities for livelihoods and through protecting lives. The peat-swamp forest provides food (wild food and fisheries), fresh water for households and agriculture, timber for construction, fibre from rattan species (Calamus manan) used to make furniture, fuel wood, natural medicines and ornamental plants. Collecting shellfish (Polymesoda sp.) and fishing might be the oldest form of livelihoods carried out in the swamp. The main fish species sought are lele or catfish (Clarias nieuhofii). 
Farmers often catch this species using traps made from bamboo and rattan. However, fisherman reported that harvests have generally declined to just $60 \%$ of former levels owing to the massive land conversion (Tata et al. 2010).

A well-functioning peat swamp provides also a regular supply of fresh water for drinking, cooking, bathing and irrigation. Production of rice - the staple food of the region-depends heavily on a stable water supply. This situation is rapidly changing because of draining the peat swamp to lower the watertable for oil-palm expansion, with water shortages and contamination reported.

The coastal peat-swamp forests are peat domes that maintain a high water table, resisting sea water intrusion into the swamp itself and preventing fires (Wösten et al. 2006, 2008). When peat swamps are drained for plantations and the peat dries and oxidizes, it shrinks, with a subsidence rate of $142 \mathrm{~cm}$ over the first 5 years (Hooijer et al. 2011) and $5 \mathrm{~cm}$ per year over subsequent decades, according to even the most conservative scenarios (Hooijer et al. 2011; Hooijer et al. 2006; Wosten and Ritzema 2002). Subsidence near the coast leads to the serious problem of increasing land salinity, which eventually precludes agricultural production, even in the oil-palm plantations themselves.

The local communities in Tripa reported a marked increase in both the frequency and extent of floods since 2000 with the extension of the oil-palm concession areas (YEL/PanEco 2008). In 2010, peat areas in Tripa were flooded with depths ranging 1-1.5 $\mathrm{m}$, isolating the communities living in and around Tripa (Serambi News 2010).

The Tripa peat-swamp forest regulates a micro-climate that benefits adjacent agriculture, including the large oil-palm plantations. Indeed, the highest palm-oil yields in the world - more than eight tonnes of crude palm-oil per hectare per year-are recorded in this region (Jacquemard et al. 2010).

\subsection{Alternative options for "high C stock development" and employment generation (Q v)}

FALLOW modelling scenarios in Tripa highlighted the need to consider both livelihoods and emission levels as dynamic baselines. A BAU scenario for the landscape suggests that all remaining forest could be converted to oil palm within a few years because labour and capital to do so are available in the landscape and oil palm is the system of choice for local agents.

A number of "ecological restoration" scenarios were evaluated (Fig. 7) that differed in their time frames (instantaneous for revoking all existing permits versus gradual for allowing existing oil palm to last to the end of its concession permit but not renewing the permit) and spatial extent (whole landscape within the Leuser Ecosystem boundaries or focus on a corridor to connect the remaining swamp forest to the Gunung Leuser National Park).

The various scenarios can be compared in their effects on local income and changes in $\mathrm{C}$ stock (Fig. 8). Compared to the current situation, which is taken as the origin in the graph, a BAU scenario adds approximately IDR 1 million per capita per year for all inhabitants of the area and loses about $0.3 \mathrm{Gg}$ of $\mathrm{CO}_{2} \mathrm{e}$ year ${ }^{-1}$. The various restoration scenarios lead to a loss of income compared to current levels but will lead to a net sequestration of $\mathrm{CO}_{2}$ approximately proportional to the loss of income.

The trade-off described by the slopes of the lines in Fig. 8 refers to a predicted outcome by multiple decision-makers. The scenarios include the response options farmers have in the presence or absence of new oil-palm developments or ecological restoration. The size of this response can be calculated as follows. The difference between BAU and year 2009 was 17,000 ha of oil palm. At 57 person-days $\mathrm{ha}^{-1}$ year $^{-1}$ and a return to labour of IDR 71,000 day $^{-1}$, this oil-palm area could generate USD 7.5 million year ${ }^{-1}$. However, in the absence of oil-palm development, the $17,000 \times 57$ person-days could be spent in other ways of 


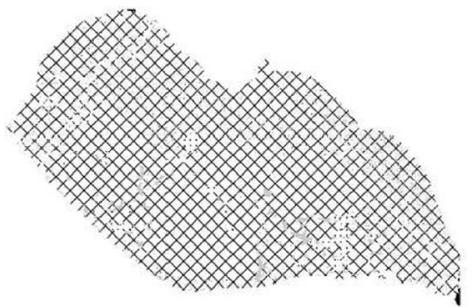

A) Business as usual

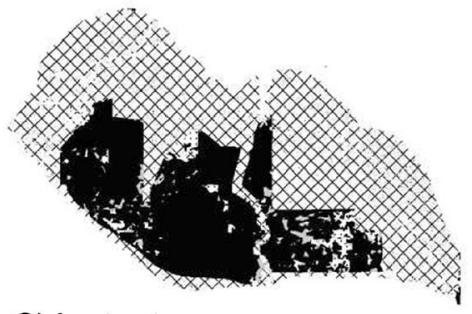

C) Instantaneous

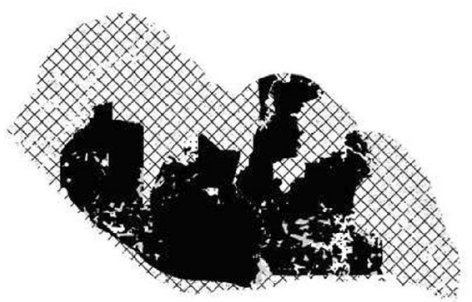

E) Corridor

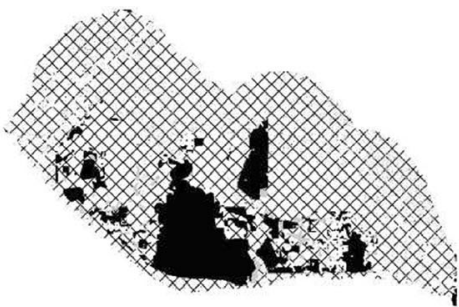

B) Patch

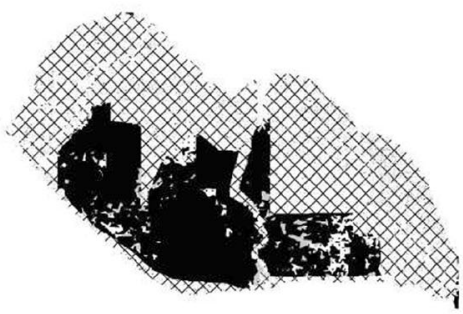

D) Gradual

\section{Legend}

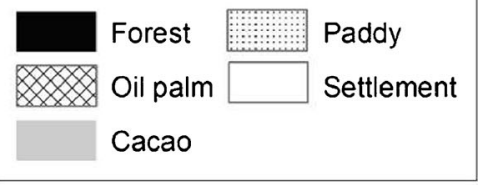

Fig. 7 Landscape mosaic in Tripa after 30 years. Simulation of five different scenarios by the FALLOW model: (i) business as usual (BAU); (ii) conservation of remaining forests ("patch"); (iii) instantaneous restoration of all oil-palm plantations to forests ("instantaneous"); (iv) gradual restoration ("gradual"); and (v) establishment of two corridors to support orangutan preservation ("corridor"). The total simulated area was 104,000 ha, including 40,000 ha in all concession areas combined

generating income. Within the parameter values of the model, USD 4.5 million of the USD 7.5 million could be internally compensated, leaving USD 3 million, or approximately IDR 1 million (approximately USD 100) per capita per year, given a projected 2030 population of 29,000 with a population density of 25 people per $\mathrm{km}^{2}$ (certainly much less within the peat swamp but most likely much more in the buffer zone) for the 102,000 ha of the swamp and its surroundings. While in Fig. 6 the implication was that the USD value of the opportunity costs would have to be paid to a rights-holder, the interpretation now is that somehow investments in the area have to generate an equivalent level of income opportunities. In that sense, the scenarios are not prescriptive of how to achieve such a goal but they do quantify a required bottom line.

\section{Discussion}

Answers to questions $\mathrm{i}-\mathrm{v}$ position the Tripa area at the heart of the current REDD + debate but also point to roles for the moratorium and for changes in behaviour of oil-palm companies in response to consumer pressure. 


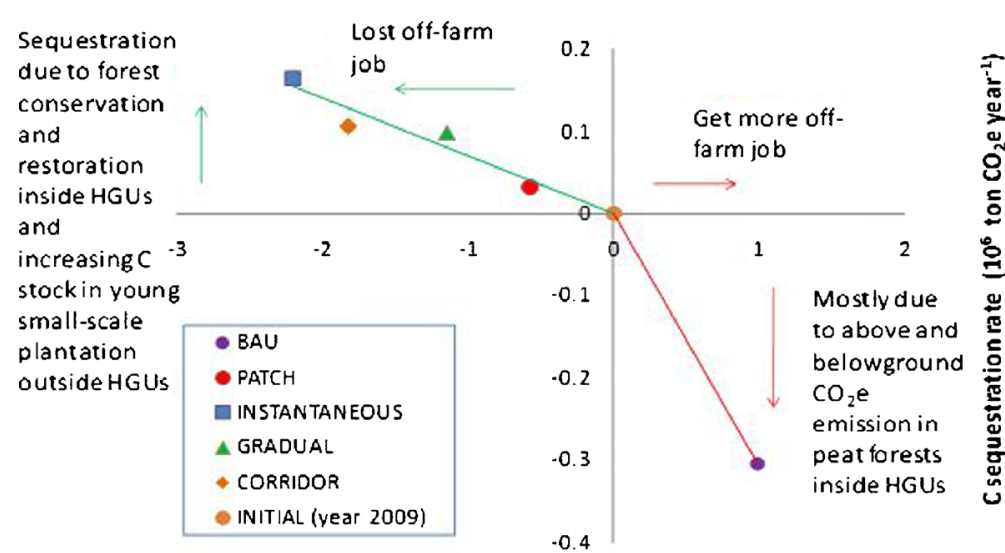

Alncome $\left(10^{6}\right.$ Rp capita-1 year $\left.{ }^{-1}\right)$

Fig. 8 Difference in annual income and annual $\mathrm{CO}_{2}$ e sequestration rate calculated with the FALLOW model for each simulation scenario for a 30-year simulation over the simulated landscape in Tripa relative to the condition measured in year 2009 (i.e. income of IDR $3.5 \times 10^{6}$ capita $^{-1}$ or IDR $6.5 \times 10^{6}$ labour $^{-1}$ with a labour fraction of 0.54 from total population in Tripa) and total aboveground carbon stock of $5.5 \times 10^{6} \mathrm{Mg}$ in the landscape); the wage rate for a labourer in large oil-palm plantations used to calculate income was $\mathrm{Rp} 1.2 \times 10^{6} \mathrm{month}^{-1}$ )

The case can be summarized as follows: in an area of high above- and belowground $\mathrm{C}$ stock, with forests that still represent globally important biodiversity (several percent of global population of critically endangered Sumatran orangutan and one of the last remaining habitat for several endangered plants, birds and other animals), privately profitable economic activities take place, mostly in the form of conversion of forests to oil-palm plantations with associated drainage of peat domes, which leads to high carbon emissions but also creates jobs and provides local income. After many centuries of sharing the landscape of the northern half of Sumatra, human populations and orangutan appear to have become incompatible in the $21^{\text {st }}$ century. Economic incentives are needed before any of the actors involved in current production of emissions would voluntarily change their behaviour.

A limitation of the current study is that it only includes aboveground emission estimates. Similar to what is described by Mulia et al. (2013), incorporation of peat emissions will substantially increase estimates for the same shift in Net Present Value and hence reduce apparent opportunity cost per unit $\mathrm{CO}_{2}$. It does not, however, change the total investment or compensation needed to make conservation a breakeven proposition for local stakeholders. Payments or returns on investment beyond opportunity costs are needed to generate a net benefit from their perspective. We leave inclusion of peat estimates to a later stage, because this is sensitive to details of drainage and fertilization patterns, and focus here on the level of investment needed in the area.

Before anyone will provide the necessary economic incentives to change the current pattern, however, the legality of the BAU practice needs to be confirmed. Presidential Decree no. 32/1990 and Indonesian Government Regulation no. 26/2008 state that all peatland with a peat of depth exceeding $3 \mathrm{~m}$ should automatically be assigned protected status and its water retention and regulatory functions should be maintained. The degazettement of Tripa as protection forest and issuance of concessions was not aligned with these rules as the core of each peat dome has more than $3 \mathrm{~m}$ of peat. Direct payment of compensation to concession holders might not be appropriate for this reason. But other local stakeholders who expect to benefit from oil-palm expansion through jobs (e.g. local people) and taxes (e.g. different levels of government, particularly, the local governments) do need consideration. 
The necessary economic incentives to protect the remaining peat-swamp forest do not necessarily mean direct cash payments to all people living in the district. Part of any funds could be used to finance activities to secure different environmental services (e.g. carbon stock, biodiversity conservation, fish ponds, water retention, wood supply) that the peat swamps provide. When related to biodiversity, for example, activities could include promotion of tourism or further research. Rehabilitation of the peat swamp for fish ponds and water retention could be carried out through careful watertable management and selective reforestation.

The apparent need for funds could also be partially internally generated through the direct contribution-unaccounted for in the current comparison-of the peat-swamp forest to the local economy (e.g. fish, freshwater supply, buffer zone against tsunami). The FALLOW model incorporated only limited data on harvesting of non-timber forest products as an economic benefit of this habitat, not the other types of ecosystem services. As for who should pay for securing the area, we might refer to who is responsible for it and who most benefits from it. When it comes to biodiversity and carbon preservation, international donors might have to be the biggest contributors. When it comes to providing secure local livelihoods, government agencies might be ultimately responsible, along with local communities and a private sector that benefits from a well-functioning ecosystem, for example, for the microclimate important for agriculture, including large oil-palm plantations.

Tripa became iconic as a case study of the failure of multiple conservation efforts in the face of economic and political pressures related to oil-palm development. In response to national and international "shaming", however, a new commitment emerged in the central government agency tasked with streamlining government procedures. After a court ruling that denied the governor's permit for further land clearing for oil palm, Tripa has now been selected as a symbol of the turnaround in government actions to achieve conservation aligned with international efforts based on multiple layers of motivation (van Noordwijk et al. 2013).

Another lesson from this study is that Tripa is a segregated landscape with a dichotomy of natural forest and intensively managed oil palm. There is little land use of intermediate intensity (van Noordwijk et al. 2012). Although Tripa is included in Indonesia's indicative map of forest and peat moratorium areas, it has not so far been considered to be a priority for a REDD + scheme. The area is designated as other use (APL, which implies non-forest), having been declassified from "protection" forest status. Existing public policy commitments to support conservation in the Leuser Ecosystem have not had tangible impact on the ground and a strong case can be made for 'de facto additionality' of new efforts to reduce emissions, even though on paper the area is already protected.

Acknowledgments The Tripa study was financially supported through the Great Apes Survival Programme of the United Nations Environment Programme through a grant to PanEco. Additional support was obtained through a grant ('Global architecture for reducing emissions from all land uses') from the Norwegian Agency for Development Cooperation to the World Agroforestry Centre. The Biodiversity and Agricultural Commodities Program of the International Finance Corporation provided additional funding to PanEco. We highly appreciate the cooperation of local government officials and villagers. Comments from Ms Betha Lusiana and anonymous reviewers helped to improve the manuscript.

Open Access This article is distributed under the terms of the Creative Commons Attribution License which permits any use, distribution, and reproduction in any medium, provided the original author(s) and the source are credited. 


\section{References}

Aceh Green (2008) Concept paper: Green economic development and investment strategy for Aceh, Indonesia. http://www.aceh-eye.org/data_files/english_format/economic/economic_analysis/eco_analysis_2008_07 00.pdf. Cited 26 Feb 2011

Agus F, Wahdini W (2008) Assessment of carbon stock of peatland at Tripa, Nagan Raya District, Nangroe Aceh Darussalam Province of Indonesia. Indonesian Centre for Agricultural Land Resources Research and Development; World Agroforestry Centre (ICRAF) Southeast Asia Regional Program; PanEco; Yayasan Ekosistem Leuseur; Universitas Syiah Kuala, Bogor

Bayas JL, Marohn C, Dercon G, Dewi S, Piepho H, Joshi L, van Noordwijk M, Cadisch G (2011) Influence of coastal vegetation on the 2004 tsunami wave impact in West Aceh. Proc Natl Acad Sci U S A 108(46): 18612-18617. doi:10.1073/pnas. 1013516108

Butler RA, Koh LP, Ghazoul J (2009) REDD in the red: palm oil could undermine carbon payment schemes. Conserv Lett 2:67-73

Cochard R, Ranamukhaarachchi SR, Shivakoti GP, Shipin OV, Edwards PJ, Seeland KT (2008) The 2004 tsunami in Aceh and Southern Thailand: a review on coastal ecosystems, wave hazards and vulnerability. Perspect Plant Ecol 10:3-40

Galudra G, Sirait MT, Pasya G, Fay CC, Suyanto S, van Noordwijk M, Pradhan U (2010) RaTA: A Rapid Land Tenure Assessment manual for identifying the nature of land tenure conflicts. World Agroforestry Centre (ICRAF) Southeast Asia Regional Program, Bogor

Gaveau D, Wich S, Epting J, Juhn D, Kanninen M, Leader-Williams N (2009) The future of forests and orangutans (Pongo abelii) in Sumatra: predicting impacts of oil palm plantations, road construction, and mechanisms for reducing carbon emissions from deforestation. Environ Res Lett 4:034013

Hairiah K, Dewi S, Agus F, Velarde SJ, Ekadinata A, Rahayu S, van Noordwijk M (2011) Measuring carbon stocks across land use systems: a manual. World Agroforestry Centre (ICRAF) Southeast Asia Regional Program, Bogor

Harja D, Dewi S, van Noordwijk M, Ekadinata A, Rahmanulloh A, Johana F (2012) REDD Abacus SP: buku panduan pengguna dan software. World Agroforestry Centre (ICRAF) Southeast Asia Regional Program, Bogor

Hooijer A, Silvius M, Wosten H, Page S (2006) PEAT- $\mathrm{CO}_{2}$ : Assessment of $\mathrm{CO}_{2}$ emissions from drained peatlands in SE Asia. Delft Hydraulics Report Q3943/2006. http://peat-co2.deltares.nl

Hooijer A, Page S, Jauhiainen J, Lee WA, Lu XX, Idris A, Anshari G (2011) Subsidence and carbon loss in drained tropical peatlands: reducing uncertainty and implications for $\mathrm{CO}_{2}$ emission reduction options. Biogeosci Discuss 8:9311-9356

Intergovernmental Panel on Climate Change [IPCC] (2006) IPCC guidelines for national greenhouse gas inventories. http://www.ipcc-nggip.iges.or.jp/public/2006gl/index.html

Jacquemard JCh, Suryana E, Cochard B, De Franqueville H, Breton F, Syaputra I, Dermawan E, Permadi P (2010) Intensification of oil palm (Elaeis guineensis Jacq.) plantation efficiency through planting material: new results and developments. Paper presented at IOPC "Transforming Oil Palm Industry", 1-3 June 2010, Jogja Expo Center, Yogyakarta

Koh LP, Wilcove DS (2007) Cashing in palm oil for conservation. Nature 448:993-994

Laumonier Y, Uryu Y, Stüwe M, Budiman A, Setiabudi B, Hadian O (2010) Eco-floristic sectors and deforestation threats in Sumatra: identifying new conservation area network priorities for ecosystem-based land use planning. Biodivers Conserv 19:1153-1174

Lusiana B, van Noordwijk M, Suyamto D, Joshi L, Cadisch G (2011) Users' perspectives on validity of a simulation model for natural resource management. Int J Agric Sustain 9(2):364-378

Ministry of Forestry and Estate Crops (1998) Peta tata guna hutan kesepakatan Aceh. http://www.dephut.go.id/ halaman/Peta\%2520Tematik/Tghk/TGACEH.GIF. Cited 20 May 2013

Minnemeyer S, Boisrobert L, Stolle F, Muliastra YIK, Hansen M, Arunarwati B, Prawijiwuri G, Purwanto J, Awaliyan R (2008) Interactive atlas of Indonesia's forests. CD-ROM. World Resources Institute, Washington DC

Mulia R, Widayati A, Suyanto, Agung P, Zulkarnain MT (2013) Low carbon emission development strategies for Jambi, Indonesia: simulation and trade-off analysis using the FALLOW model. Mitig Adapt Strateg Glob Chang. doi:10.1007/s11027-013-9485-8

Murdiyarso D, Dewi S, Lawrence D, Seymour F (2011) Indonesia's forest moratorium: a stepping stone to better forest governance? Center for International Forestry Research, Bogor

Nantha HS, Tisdell C (2009) The orangutan-oil palm conflict: economic constraints and opportunities for conservation. Biodivers Conserv 18:487-502

NASA/University of Maryland (2002) Fire events plotted from MODIS Terra and Aqua satellite data from Nov. 2000 to Feb. 2011 provided by the Fire Information for Resource Management System (FIRMS). College Park 
Russon AE, Wich SA, Ancrenaz M, Kanamori T, Knott CD, Kuze N, Morrogh-Bernard HC, Pratje P, Ramlee H, Rodman P, Sawang A, Sidiyasa K, Singleton I, van Schaik CP (2007) Geographic variation in orangutan diets. In: Wich S, Atmoko SU, Setia TM, van Schaik CP (eds) Orangutans geographic variation in behavioural ecology and conservation. Oxford University Press, Oxford, pp 135-156

Ruysschaert D, Singleton I, Sudarman S (2009) Inappropriate land use in the coastal Tripa peat swamps on the West coast of Aceh. Paper presented at International Conference on Natural and Environmental Sciences, Banda Aceh, Indonesia, 6-8 May, 2009

Ruysschaert D, Darsoyo A, Rizwan, Gea G, Singleton I, van Noordwijk M (2011) Developing palm-oil production on fallow land: technical, economic, biodiversity, climate, legal and policy implications. PanEco Foundation, Medan. http://www.paneco.ch/webautor-data/7/oilpalm-dev-on-degraded-land.pdf. Cited 31 July 2013

Serambi News (2010) Ribuan warga Nagan terkurung banjir (Thousands of Nagan people isolated by flooding). 24 September 2010

Stern N (2007) The economics of climate change: The Stern review. Cambridge University Press, Cambridge, http://webarchive.nationalarchives.gov.uk/+/http://www.hmtreasury.gov.uk/stern_review_report.htm

Suyamto D, Mulia R, van Noordwijk M, Lusiana B (2009) FALLOW 2.0. Manual and software. World Agroforestry Centre (ICRAF) Southeast Asia Regional Program, Bogor

Swallow BM, van Noordwijk M, Dewi S, Murdiyarso D, White D, Gockowski J, Hyman G, Budidarsono S, Robiglio V, Meadu V, Ekadinata A, Agus F, Hairiah K, Mbile P, Sonwa DJ, Weise S (2007) Opportunities for avoided deforestation with sustainable benefits: an interim report of the ASB partnership for the Tropical Forest Margins. ASB Partnership for the Tropical Forest Margins. Working Paper 42. Nairobi. http://www. worldagroforestry.org/sea/Publications/searchpub.asp?publishid=1784

Tata HL, van Noordwijk M, Mulyoutami E, Rahayu S, Widayati A, Mulia R (2010) Human livelihoods, ecosystem services and the habitat of the Sumatran orangutan: Rapid assessment in Batang Toru and Tripa. World Agroforestry Centre (ICRAF) Southeast Asia Regional Program, Bogor

The Independent (2009) Oil boom threatens the last orang-utans. Tuesday 23 June. http://www.independent.co. uk/environment/nature/oil-boom-threatens-the-last-orangutans-1714157.html. Cited 28 May 2013

Tomich TP, van Noordwijk M, Budidarsono S, Gillison A, Kusumanto T, Murdiyarso D, Stolle F, Fagi AM (2001) Agricultural intensification, deforestation, and the environment: Assessing tradeoffs in Sumatra, Indonesia. In: Lee DR, Barrett CB (eds) Tradeoffs or synergies? Agricultural intensification, economic development and the environment. CAB International, Wallingford, pp 221-244

Van Belle J, Hennin T (2008) Above ground carbon assessment coastal peat swamp rain forest of Tripa, Nanggroe Aceh Darussalam Province, Indonesia. Internal report. PanEco, Medan

Van Noordwijk M (2002) Scaling trade-offs between crop productivity, carbon stocks and biodiversity in shifting cultivation landscape mosaics: the FALLOW model. Ecol Model 149:113-126

Van Noordwijk M, Suyamto DA, Lusiana B, Ekadinata A, Hairiah K (2008) Facilitating agroforestation of landscapes for sustainable benefits: tradeoffs between carbon stocks and local development benefits in Indonesia according to the FALLOW model. Agric Ecosyst Environ 126:98-112

Van Noordwijk M, Tata HL, Xu J, Dewi S, Minang P (2012) Segregate or integrate for multifunctionality and sustained change through landscape agroforestry involving rubber in Indonesia and China. In: Nair PKR, Garrity DP (eds) Agroforestry: The future of global landuse. Springer, Amsterdam, pp 69104

Van Noordwijk M, Agus F, Dewi S, Purnomo H (2013) Reducing emissions from land use in Indonesia: motivation, policy instruments and expected funding streams. Mitig Adapt Strateg Glob Chang. doi:10. 1007/s11027-013-9502-y

Venter O, Meijaard E, Possingham H, Dennis R, Sheil D, Wich S, Hovani L, Wilson K (2009) Carbon payments as a safeguard for threatened tropical mammals. Conserv Lett 2:123-129

Wahyunto, Ritung S, Subagjo H (2003) Peta luas sebaran lahan gambut dan kandungan karbon di Pulau Sumatera 1990-2002. Wetlands International Indonesia Program; Wildlife Habitat Canada, Bogor. http:// www.wetlands.or.id/PDF/buku/Atlas\%20Sebaran\%20Gambut\%20Sumatera.pdf

White D, Minang P, Agus F, Borner J, Hairiah K, Gockowski J, Hyman G, Robiglia V, Swallow B, Velarde S, van Noordwijk M (2010) Estimating the opportunity costs of REDD+: A training manual. World Bank, Washington DC

Wich SA, Meijaard E, Marshall AJ, Husson S, Ancrenaz M, Lacy RC, van Schaik CP, Sugardjito J, Simorangkir T, Taylor-Holzer K, Doughty M, Supriatna J, Dennis R, Gumal M, Knott CD, Singleton I (2008) Distribution and conservation status of the orangutan (Pongo spp.) on Borneo and Sumatra: how many remain? Oryx 42:329-339

Wilcove DS, Koh LP (2010) Addressing the threats to biodiversity from oil-palm agriculture. Biodivers Conserv 19:999-1007 
Wosten JHM, Ritzema HP (2002) Challenges in land and water management for peatland development in Sarawak. In: Rieley JO, Page SE, Setiadi B (eds) Peatlands for people: natural resource functions and sustainable management. Proceedings of the International Symposium on Tropical Peatland, 22-23 August 2001, Jakarta, Indonesia. BPPT and Indonesia Peat Association. pp 51-55

Wösten JHM, Hooijer A, Siderius C, Rais DS, Idris A (2006) Tropical peatland water management modelling of the Air Hitam Laut catchment in Indonesia. JRBM 4:233-244

Wösten JHM, Clymans E, Page SE, Rieley JO, Limin SH (2008) Peat-water interrelationship in a tropical peatland ecosystem in Southeast Asia. Catena 73:212-224

YEL/Paneco (2008) How palm-oil plantations at Tripa increase disaster risk, contribute to climate change and drive a unique Sumatran orangutan population to extinction. Value of Tripa peat swamp forest, Aceh, Sumatra, Indonesia. http://www.sumatranorangutan.com/webautor-data/39/Value-Tripa-9MB-15-Nov08. pdf. Cited 15 February 2011

YEL/Paneco (2010) Tripa peat swamp forest ecological situation, trends and feasibility of restoration. Report January 2010. http://www.paneco.ch/webautor-data/7/Tripa-restoration-feasibility-report_Jan-2010-1.pdf. Cited 15 February 2011

Yule s (2010) Loss of biodiversity and ecosystem functioning in Indo-Malayan peat swamp forests. Biodivers Conserv 19:393-409 